Planning and Development Committee of the Wessex Regional Hospital Board and later as Vice Chairman of the Hampshire Area Health Authority, he was deeply involved in the expansion of hospital services in the area.

He was honoured by the award of the OBE in 1978 and earlier by election to a Fellowship of the Indian Academy of Sciences.

Marine scientists the world over will grieve the loss of a man who by quiet example was able to foster participation between research workers at every level, of different interests and from many nations.

A.P.M. Lockwood

\section{Jack Tizard}

Professor JACK TIZARD died in London aged sixty, on 2 August 1979, as a result of cancer found to be inoperable eight months earlier. So passed one of the foremost postwar research workers in mental retardation and child development.

Born a New Zealander, Jack graduated there and after overseas Army services undertook a postgraduate degree at Oxford where he met his wife. In 1948 he joined the Medical Research Council's Social Psychiatry Research Unit at the Institute of Psychiatry in London, and with his colleague Neil O'Connor was directed by Professor Aubrey Lewis into the neglected field of mental deficiency. He was appalled by the situation he found in hospitals for the mentally defective which in those days were used as places where socially disadvantaged young people could be put away. As a fearless man he said so, among other things challenging the medical model which was enshrined in the 1913 Mental Deficiency Act. Tizard and O'Connor set about showing that industrial habilitation leading to fairly rapid discharge from care was a viable possibility. Their pioneering studies on the mildly retarded were brought together in 1956 in an important book The Social Problem of Mental Deficiency.

However, there was more to do. There remained the moderately and severely retarded who were on the whole considered unemployable in even the simplest capacity. In a series of innovatory experiments it was shown that young adults with intelligence quotients in the thirties and forties could in certain circumstances learn, respond to incentives, retain their learning and transfer it to rather different situations. Others built upon and extended this work which cast new light on our potential for helping the more severely disabled, and their own potential for change.

Jack himself was ready to move on, and with the help of Dr Leslie Hilliard transferred a number of mentally handicapped children out of the Fountain Hospital and into a country house which resembled a boarding school. In 1961 he published The Mentally Handicapped and Their Families (with J.C. Grad) and in 1964 Community Services for the Mentally Handicapped. His belief that the quality of the social structure and organization of any community is a major determinant of development and behaviour of its members led him into the field of social policy.

In 1964 Jack was appointed to the first Chair in Child Development at the University of London; his outstanding contribution to the study of mental subnormality was acknowledged in 1968 when, jointly with Neil O'Connor, he received the Kennedy International Scientific Award, to be followed in 1973 by the annual research award of the American Association on Mental Deficiency. In the early nineteen-seventies, as Research Professor, he founded The Thomas Coram Research Unit, a unique multi-disciplinary establishment in which medical and a variety of social scientists collaborated in policy-oriented research projects. His erudition, high intelligence and unusually attractive personality ensured that he became much in demand for committee work. An excellent and incisive chairman, he was invited to act in several different capacities for a large number of organizations including the Social Science Research Council, the Department of Health and Social Security, the Association for Child Psychology and Psychiatry, the WHO Expert Committee on Mental Health, and for the British Psychological Society as president. He was appointed CBE in 1973.

Despite his generous contribution to committees, his research continued to flourish, and a steady flow of books and articles appeared over the years on a wide variety of topics relating to children. Jack Tizard was an example of that unusually effective individual, a radical thinker accepted by the Establishment.

In the final eight months, much of it in pain, Jack's bearing befitted his life. Fortitude, equanimity and hard work were his daily purposes; his courage was well matched by that of Barbara, his wife. Their long, happy marriage must have given both a background of security, and contributed in no small measure to the success each enjoyed.

To say of a man that "we shall not see his like again" is often a sentimental exaggeration; in the case of Jack Tizard, this is not the case. Those hundreds of us who knew him personally must feel a deep sense of loss at his passing.

Ann Clarke and Alan Clarke

\section{Marcel Florkin}

BORN in Liège, Belgium in the first year of the new century (15 August 1900), Marcel Florkin died in Liège on 3 May 1979. His early education and his medical degree were also at Liège, but thereafter he gained international recognition through his con- tributions in the areas of invertebrate physiology, comparative biochemistry and physiology, biochemical evolution, and origin of life, as well as through numerous roles in the development of international aspects of biochemistry.

Florkin's interest in physiology and biochemistry were increased by study in the laboratories of such eminent scientists as Joseph Barcroft, Richard Kuhn, Heinrich Wieland, and Edwin Cohn, following which he spent 36 years in teaching and research at the University of Liège, interrupted by visiting professorships at Duke University and the Universities of Washington and Oregon.

Perhaps the most compelling urge of his life in science was to extend his interests and contributions beyond ordinary limits, into broadly related areas of history, comparative aspects of physiology and biochemistry, evolution, and the nature of men who have contributed uniquely to the field of biological science. In addition to his numerous individual contributions, he undertook prodigious tasks of assembling as senior editor the world's contributions in multi-volume collections in various fields. Witness the ten volumes of Chemical Zoology, the seven volumes of Comparative Biochemistry (Florkin and Mason), and the 34 volumes of Comprehensive Biochemistry (Florkin and Stotz). The last five volumes of the latter series were devoted to the History of Biochemistry, his own contribution, and constituting written testimony to his critical and intimate knowledge of the great events in biochemistry. Included in his History is a remarkable collection of photographs of pioneers in biochemistry, itself a notable tribute to his perseverance and human touch.

Florkin contributed greatly to the role of biochemistry at the international level. In 1952 he became chairman of the International Committee of Biochemistry, and in 1955 was named the first President of the newly formed International Union of Biochemistry, following which he was instrumental in gaining admission of the newly formed Union into the International Council of Scientific Unions. As first Treasurer of the Union, the writer can attest to the diplomatic skills and warm spirit of negotiation displayed by Professor Florkin.

Marcel Florkin gained many honors and awards in his active life, including honorary membership in the Royal Institution of Great Britain and honorary fellowship in the Royal Society of Edinburgh. Yet in his busy life he maintained an active interest in the arts, and seldom missed an opportunity in his travels to find a moment for a visit to the local art museums to view their recent acquisitions. It is not surprising that he was devoted to family and close friends, who, along with many scientific colleagues, will miss his great warmth and human spirit.

Elmer H. Stotz 